\title{
PENGARUH SISTEM INFORMASI KEUANGAN DESA (SISKEUDES) TERHADAP KINERJA KEPALA DESA \\ (Studi Kasus Desa Tokaka, Kecamatan Gane Barat Utara, Kabupaten Halmahera Selatan )
}

\section{THE INFLUENCE OF THE VILLAGE FINANCIAL INFORMATION SYSTEM (SISKEUDES) ON THE PERFORMANCE OF THE VILLAGE HEAD (Case Study of Tokaka Village, Gane Barat District, South Halmahera Regency)}

\author{
Muksin Hi. Abdullah ${ }^{1}$, Abjan Samad ${ }^{2}$ \\ Program Studi Teknik Komputer \\ Akademi Ilmu Komputer (AIKOM) Ternate \\ muksinabdullah@gmail.com
}

\begin{abstract}
Abstrak
Tujuan penelitian ini untuk mengetahui Pengaruh Sistem Keuangan Desa (Siskeudes) terhadap Kinerja Kepala Desa sebagai penyelenggaran Pemerintahan di Desa Tokaka, Kecamatan Gane Barat, Kabupaten Halmahera Selatan. Penelitian ini menggunakan data primer berupa hasil observasi, wawancara, dan data sekunder. Sedangkan Informan yang digunakan adalah Kepala Desa, Operator Sistem Keuangan Desa (Siskeudes), Sekretaris Desa, Bendahara Desa, Kaur Keuangan serta Kasi pada pemerintah desa. Hasil penelitian menunjukkan, penginputan data pada Sistem Keuangan Desa (Siskeudes) harus sesuai dengan yang tertera dalam sistem; sedangkan kesediaan Sumber Daya Manusia (SDM) yang tidak mendukung sehingga perlu dilakukan peningkatan kapasitas melalui pendampingan atau pelatihan yang mengakibatkan Penerapan Sistem Keuangan Desa (Siskeudes) belum memberikan dampak positif terhadap kinerja Kepala Desa. Dari hal tersebut maka pengaruh Sistem Keuangan Desa (Siskeudes) belum memilliki pengaruh signifikan terhadap kinerja kepala desa sebagai penyelenggaaran pemerintahan di tahun anggaran pertama (TA. 2015) khususnya dalam pengelolaan administrasi Dana Desa (DD) dan Anggaran Dana Desa (ADD) yang dirasakan langsung oleh para pemerintah desa di Desa Tokaka. Hal ini berbanding terbalik dengan tujuan diimplentasikannya Sistem Keuangan Desa (Siskeudes) untuk membantu kerja penyelenggaran pemerintah desa secara adminitstratif.
\end{abstract}

\section{Kata Kunci: Pengaruh, Siskeudes, Kinerja, Kepala Desa}

\begin{abstract}
The purpose of this research is to know the influence of the financial system of the village (Siskeudes) against the performance of the Chief of the village, as the organizer of the Government in Tokaka Village Gane Barat District, South Halmahera Regency, This study uses primary data in the form of observations, interviews, and secondary data, While the Informant used was the village head, Village financial system Operators (Siskeudes), village secretary, Village Treasurer, Finance Chief, and Kasi to the village government, The results of the study show that inputting data in the Village Financial System (Siskeudes) must be in accordance with the system, while the willingness of Human Resources (HR) is not supported
\end{abstract}


so that capacity building needs to be done through mentoring or training, which resulted in the Implementation of the Village Financial System (Siskeudes) not having a positive impact on the performance of the Village Head, From this, the influence of the Village Financial System (Siskeudes) has no significant influence on the performance of the village head as the administration of the government in the first fiscal year (TA. 2015), especially in the administration of Village Funds $(D D)$ and Village Funds $(A D D)$ funds which are felt directly by village governments in Tokaka Village, This is inversely proportional to the purpose of the implementation of the Village Financial System (Siskeudes) to assist the administration of village administration in an administrative.

\section{Keywords: Influence, Siskeudes, The Performance, Village head}

\section{PENDAHULUAN}

Seiring dengan diiplementasikannya Undang-undang No. 6 Tahun 2014, desa merupakan suatu pengakuan (subsiedaritas) negara terahadap keberadaan desa. Desa sebagai subjek utama dalam menentukan masa depannya sendiri bukan merupakan objek bagi pemerintah, maupun pemerintah daerah. Pada sistem pemerintahan yang ada dan berlaku saat ini, desa mempunyai peran yang strategis dan penting dalam membantu pemerintah daerah dalam proses penyelenggaraan pemerintahan, termasuk pembangunan. Pelaksanaan APBDesa memiliki peran penting dalam mensukseskan pembangunan daerah. Anggaran Pendapatan dan Belanja Desa (APBDesa) dapat menjadi cerminan kinerja dan kemampuan pemerintah desa dalam membiayai dan mengelola penyelenggaraan pemerintah dan pelaksaan pembangunan di desa. Pada kenyataannya banyak ditemukan keluhan masyarakat yang berkaitan dengan pengalokasian anggaran yang tidak sesuai dengan kebutuhan skala prioritas, serta kurang mencerminkan aspek ekonomi, efisiensi, dan efektivitas.

Anggaran desa yang didistribusikan dari pusat akhir-akhir ini banyak diselewengkan karena kurangnya pemahaman aparat desa dalam mengelola anggaran. Sehingga anggaran yang selama ini diharapkan dapat digunakan untuk memajukan desa disalahgunakan oleh oknum-oknum tertentu. Hal demikian tentunya sudah lazim di negeri ini, sehingga tindakantindakan yang menyimpang tersebut perlu diwaspadai dan diantisipasi. Sebab perbuatan ini akan merugikan dan juga menghambat kemajuan dan juga berefek pada desa itu sendiri.

Sistem informasi akuntansi sangat dibutuhkan untuk mengatasi hal tersebut. Sebuah sistem terdiri dari bagian-bagian yang bergabung untuk suatu tujuan tertentu. Sistem informasi akuntansi merupakan suatu sistem yang mengumpulkan, mencatat, menyimpan, dan mengolah data untuk mengahasilkan informasi bagi pengambil keputusan. Sistem ini meliputi orang, prosedur dan intruksi, data, perangkat lunak, infrastruktur teknologi informasi, serta pengendalian internal dan ukuran keamanan. Adapun fungsi dari sistem informasi akuntansi yaitu: (1) memberikan sistem informasi akuntansi yang tepat waktu, (2) memberikan sistem informasi akuntansi yang relevan; (3) memberikan sistem informasi akuntansi yang dapat dipercaya, (Romney (2014). Hingga saat ini, berdasarkan data yang disampaikan Dinas Pemberdayaan Masyarakat dan 
Desa (DPMD) Kabupaten Halmahera Selatan, dalam menyampaikan pelaporan penggunaan Dana Desa (DD) rata-rata masih secara manual, tingkat implementasi Siskeudes di Kabupaten Halmahera Selatan belum signifikansi terhadap jumlah desa. Dari 249 Desa di Kabupaten Halmahera Selatan hanya $8 \%$ yang dalam pelaporannya menggunakan SISKEUDES, desa-desa inipun yang lokasinya dengan dengan ibukota kabupaten yang telah memiliki Sumber Daya Manusia (SDM) terutama bendahara dan operatornya yang sudah mampu menjalan atau mengoperasikan SISKEUDES.

Sistem Keuangan Desa (SISKEUDES) merupakan aplikasi yang dikembangkan Badan Pengawasan Keuangan dan Pembangunan (BPKP) dalam rangka meningkatkan kualitas tata kelola keuangan desa. Tujuan dari diterapkannya Sistem Keuangan Desa (SISKEUDES) adalah untuk memudahkan dalam pelaporan keuangan. Selain itu juga untuk menata kelola keuangan desa secara optimal serta sebagai alat kendali/tolak ukur pengelolaan keuangan desa sehingga tidak keluar dari koridor peraturan undangundang.

Penerapan Sistem Keuangan Desa (SISKEUDES) ini tentu memiliki kelebihan dan kelemahan. Adapun kelebihan dari sistem keuangan desa (Siskeudes) ini yaitu (1) sesuai peraturan, (2) memudahkan tata kelola keuangan desa, (3) kemudahan penggunaan aplikasi, (4) dilengkapi dengan sistem pengendalian intern (Built-in Internal Control), (5) didukung dengan petunjuk pelaksanaan implementasi dan manual aplikasi. Disamping kelebihan tersebut, kelemahan dari Sistem Keuangan Desa (SISKEUDES) ini yaitu sulitnya memahami penggunaan aplikasi ini karena aplikasi yang masih baru diterapkan sehingga para pegawai sulit untuk mengaplikasikannya. Selain itu kuranganya pelatihan penggunaan Sistem Keuangan Desa (SISKEUDES) yang diberikan bagi para pegawai.

Berdasarkan hal tersebut maka peneliti tertarik untuk melakukan penelitian mengenai "Pengaruh Sistem Keuangan Desa (SISKEUDES) terhadap Kinerja Pemerintah Desa (Studi Kasus di Desa Tokaka, Kecamatan Gane Barat Utara, Kabupaten Halmahera Selatan)".

\section{Rumusan Masalah}

Bagaimana mengetahui Pengaruh dan Dampak dari Penggunaan Sistem Informasi Keuangan Desa (SISKEUDES) di Desa Tokaka Kabupaten Halmahera Selatan.

\section{LANDASAN TEORI \\ Sistem Keuangan Desa (Siskeudes)}

Aplikasi tata kelola keuangan desa ini pada awalnya dikembangkan Perwakilan BPKP Sulawesi Barat sebagai proyek percontohan di lingkungan BPKP pada bulan Mei 2015. Aplikasi ini telah diimplementasikan secara perdana di Pemerintah Kabupaten Mamasa pada bulan Juni 2015. Keberhasilan atas pengembangan aplikasi ini selanjutkan diserahkan kepada Deputi Kepala BPKP Bidang Pengawasan Penyelenggaran Keuangan Daerah setelah melewati tahapan Quality Assurance (QA) oleh Tim yang telah ditunjuk. Terhitung mulai tanggal 13 Juli 2015 aplikasi keuangan desa ini telah diambil alih penanganannya oleh Deputi Bidang Penyelenggaraan Keuangan Daerah di Jakarta. Dan pada akhir Tahun 2015 melalui pengembangan BPKP bersama Kementerian Keuangan dan Kementerian Desa menyepakati 
bersama aplikasi ini dignakan sebagai alat dalam pelaporan tatakelo realisasi keuangan desa yang juga bersumber dari Angaran Pendapat dan Belanja Negara (APBN)

Aplikasi keuangan desa ini menggunakan database Microsoft Acces sehingga lebih portable dan mudah diterapkan oleh pengguna aplikasi yang awam sekalipun. Secara teknis transaksi keuangan desa termasuk dalam kelompok skala kecil, sehingga lebih tepat ditangani secara mudah dengan database acces ini. Penggunaan aplikasi dengan menggunakan database SQL Server hanya dikhususkan untuk tujuan tertentu atau volume transaksi sudah masuk dalam kategori skala menengah.

Penggunaan aplikasi keuangan desa harus mendapatkan persetujuan dari BPKP selaku pengembang aplikasi. Pemerintah Daerah dapat mengajukan permohonan penggunaan aplikasi ini kepada Perwakilan BPKP setempat.Pengajuan penggunaan aplikasi agar dikoordinasikan oleh Pemerintah Daerah sehingga dapat diterapkan pada seluruh desa yang ada pada pemerintah daerah yang bersangkutan. Persetujuan penggunaan aplikasi dilakukan dengan cara memberikan kode validasi dan sml pemda yang dikeluarkan secara resmi oleh BPKP

\section{Pemerintah Desa}

Pemerintah desa merupakan simbol formal dari keseluruhan masyarakat desa yang mengatur pelaksanaan kegiatankegiatan dan urusan pemerintahan oleh di desa dan badan permusyawaratan yang di pilih oleh masyarakat dan untuk kepentingan masyarakat.

\section{Pengelolaan Keuangan Desa}

Pengelolaan keuangan desa adalah suatu bentuk tahap atau proses dalam mengelola keuangan desa yang terdiri dari 4 tahap yaitu perencanaan, pelaksanaan, penatausahaan dan pelaporan keuangan desa

\section{METODE PENELITIAN}

Metode yang digunakan dalam penelitian ini berupa penelitian deskriptif kualitatif yang di dalamnya memberikan penjelasan atau gambaran mengenai analisa peranan Sistem Keuangan Desa (SISKEUDES) terhadap kinerja pemerintah desa. Penelitian kualitatif menurut Gunawan (2013) merupakan sebuah metode penelitian yang digunakan dalam mengungkapkan permasalahan dalam kehidupan kerja organisasi pemerintah, swasta, kemasyarakatan, kepemudaan, perempuan, olah raga, seni dan budaya, sehingga dapat dijadikan suatu kebijakan untuk dilaksanakan demi kesejahteraan bersama.

Penelitian ini dilaksanakan di Kantor Desa Tokaka, Kecamatan Gane Barat Utara, Kabupaten Halmahera Selatan. Alasan memilih lokasi ini karena di Desa Tokaka Kecamatan Gane Barat Utara, merupakan salah satu desa yang telah menggunakan Sistem Keuangan Desa (SISKEUDES) sebagaimana yang diinstruksikan oleh BPKS melalui Dinas Pembaerdayaan Masyarakat Desa (DPMD) Kabupaten Halmahera Selatan pada Tahun Anggaran 2015. Selain itu dengan adanya penerapan Sistem Keuangan Desa (SISKEUDES) apakah di Desa Tokaka telah memberikan korelasi positif terhadap kinerja Kades sebagai penyelenggaran pemerintahan ? Sementara di sisi lain SDM pendukung terutama dalam mengoperasikan Sistem Keuangan Desa (SISKEUDES) memiliki pendidikan yang 
tergolong rendah. Hipotesis ini akan dibuktikan pada penelitian ini.

Informan dalam penelitian ini, peneliti menggunakan metode purposive sampling. Purposive sampling merupakan salah satu teknik pengambilan sampel dengan pertimbangan tertentu (Sugiyono, 2012. Informan yang ditunjuk kriterianya, yaitu berhubungan langsung denganb Siskeudes yang dianggap memahami Sistem Keuangan Desa (SISKEUDES) serta merasakan manfaat diterapkannya Sistem Keuangan Desa (SISKEUDES). Adapun informan yang ditunjuk yaitu: Kepala Desa, Sekretaris Desa sebagai koordinator Pelaksana Teknis Pengelolaan Keuangan Desa (PTPKD), Kaur Keuangan atau operator Siskeudes, dan Bendahara Desa.

Pengumpulan data dilakukan dengan melakukan wawancara terhadap pihak pihak terkait disebutkan di atas. Informan yang telah ditunjuk diwawancarai dengan memakai teknik wawancara mendalam. Agar wawancara mendalam bisa berlangsung secara terarah, berdasarkan pedoman wawancara yang telah disipakan dengan memuat pokok-pokok pikiran yang terkait dengan masalah yang diteliti. Data hasil wawancara direkam memakai alat perekam serta ditulis menggunakan alat tulis.

Menurut Herdiansyah (2015), bahwa observasi didefinisikan sebagai suatu proses melihat, mengamati, dan mencermati serta merekam perilaku secara sistematis untuk suatu tujuan tertentu. Pada jenis observasi ini, penelitian melakukan pengamatan yang dilakukan tanpa menggunakan pedoman observasi, sehingga peneliti mengembangakan pengamatannya berdasarkan perkembangan yang terjadi di lapangan.

\section{IMPLEMENTASI DAN PEMBAHASAN Gambaran Umum}

Desa Tokaka secara administratif termasuk dalam wilayah kecamatan Gane Barat Utara Kabupaten Halmahera Selatan Terletak di arah barat Kabupaten Halsel, dengan jarak 9 KM dari kantor kecamatan (Dolik). Jarak Desa Tokaka dari kantor Bupati Kabupaten Halmahera Selatan sekitar 150 Mil. Waktu tempuh menuju pusat kota kecamatan sekitar 1 Jam, sedangkan waktu tempuh menuju ibukota Kabupaten kurang lebih 6 jam dengan menggunakan transportasi laut.

Desa Tokaka terdiri dari dua dusun dan 6 RT Nama nama dusun itu adalah Dusun Talaga, Dusun Salira, dengan Luas Wilayah desa Tokaka adalah 57,4 KM2 . Desa Tokaka dari Indeks Pembangunan Desa (IPD) termasuk dalam kategori desa Tertinggal (dengan nilai 39,75) sehinggap perlu ditingkatkan dalam melakukan pelayanan masyarakat di desa terutama pada bidang : (1) Indeks Pelayanan Dasar dengan nilai 26,2, (2). Indeks Kondisi Infrastruktur yakni 21,71 masih jauh dari harapan, dan (3). Indeks Pelayanan Publik sebesar 49,65. Hal inilah menjadi dasar dari kepala desa sebagai penyelengaraan pemerintah desa dalam Rencana Pembangunan Desa Menengah Desa (RPJMDes) mencanangkan dalam Visi dan Visis permintahanya yang seiring dengan implementasi UU No. 6 Tahun 2015 tentang Desa, yang didukung dengan anggaran yang bersumber dari APBN yang dialokasikan melalui Dana Desa (DD) dapat memperioritaskan visi dan misinya dalam membangun desa, dengan harapat dapat meningkatkan IPD desa 5- 6 tahun ke depan agar Desa Tokaka menju desa mandiri sebagaimana yang diamanatkan Undang-undang Desa No. 6 Tahun 2014. 
Prosedur Penggunaan Sistem Keuangan Desa (Siskeudesa) di Desa Tokaka

Prosedur

Keuangan Desa (Siskeudes) tetap berdasarkan mekanisme dalam sistem yakni dilakukan berdasarkan tahapan penarikan anggaran dan realisasi anggaran atau sesuai dengan transaksi yang dilakukan oleh desa, karena tahapan penarikan sebanyak tiga (3) kali yakni persentasi $40 \%$ : 40\% : $20 \%$. Penarikan tahap kedua memerlukan Lapaoran Pertanggung Jawaban (LPJ) tahap pertama $40 \%$, demikian penarikan tahap ketiga atau tahap terakhir LPJ tahap kedua menajdi syarat pencairan, kecuali pencairan tahap pertama $40 \%$ tidak membutuhkan LPJ karena belum ada realisasi anggaran.

Hasil penginputan dapat menghasilkan output berupa dokumen penatausahaan dan laporan- laporan yang sesuai dengan ketentuan perundang-undangan. Dalam proses pelaksanaannya, sebelum menginput data ke dalam aplikasi Siskeudes, desa harus menetapkan RAB (Rancangan Anggaran Biaya) manual yang telah dibuat sebelumnya dan telah diseseuaikan dengan yang tertera dalam system . RAB (Rancangan Anggaran Biaya) yang akan diinput tersebut merupakan rancangan yang akan digunakan untuk tahun anggaran berjalan, karena penginputan Siskeudes berdasarkan $\mathrm{RAB}$ yakni $\mathrm{RAB}$ rinci yang diuraikan berupa bidang, sub bidang dan nama kegiatan.

Seperti pendapat dari Sukri Abdurahman selaku Kaur Keuangan merangkap Bendahara Desa yang mengatakan bahwa:"Siskeudes sebenarnya merupakan salah satu alat yang digunakan oleh pemerintah dalam hal ini adalah BPKP yang dipercayakan untuk membuat sisten ini dengan tujuan mempermudah pemerintah desa dalam melakukan penataan pembukuan keuangan di desa, namun ini adalah tahun pertama, bendahara desa atau operator Siskeudes belum maksimal diberikan pelatihan atau peningkatan kapasitas tentang penginputan ke Siskeudes.

Lanjut benahara desa, memang benar apa yang dilakukan pemerintah atau BPKP ini kalau dilihat dari hasilnya sangat baik, namun siskeudes ini harus didukung oleh buku manual yakni buku kas umum (BKU), buku bank dan buku bantu pajak, tanpa ketiga buku ini sulit dalam melakukan penginputan, walaupun penginputannya berdasarkan $\mathrm{RAB}$ rinci, namun kesulitan dalam menyamakan angka dalam realisasi kegiatan atau penggunakan dana. Olehnya itu pada tahun pertama ini dipaksakan untuk digunakan siskeudes sebagai salah satu alat kontrol penatausahaan, sepertinya belum maksimal, mungkin lebih abik ditahuntahun yang akan datang dimulai Tahun Anggaran 2016, yang Sumber Daya Manusianya (SDM) telah dilatih atau didampingi oleh Pendamping Desa (PD) maupun Pendamping Lokal Desa (PLD), karena hampir semua pendamping juga belum mengetahui Siskeudes karena belum dilatih atau diberikab pelatihan.

Sementara di sisi lain Siskeudes digunakan apabila harus diawali dengan perencanaan desa yang sesuai dengan tahapannya, yakni dimulai dari penyusunan RPJMDes, RKP sampai pada APBDes yang didukung oleh Rencana Anggaran Biaya (RAB) rincinya baik infrasturktur maupun non infrastruktur dari bidang pertama sampai dengan bidang empat. Informen ini merupakan salah satu pelaku program lama yakni Tim Pengelola Kegiatan (TPK) Program pemberdayaan 
sebelumnya di desa sehingga sangat paham dengan proses perencanaan di desa.

Pendapat tersebut juga diperkuat dengan pendapat dari Bapak Jufri Ajid selaku Kasi Pembangunan yang juga sebagai pelaksana PTPKD yang secara langsung berhubungan dengan pelaksanaan kegiatan yang sering mengeluhkan lambatnya proses pencairan keuangan melalui prosedur Siskeudes secara administrasi apabila dilakukan pencairan kegiatan membutuhkan waktu lama yang menghambat pekerjaan di lapangan, mengemukakan bahwa:

"Kalau di siskeudes kan sudah diatur, sudah ada ketentuannya masing-masing, namun sangat mempengaruhi pelaksanaan kegiatan, di satu sisi. Sementara di sisi lain ketika saat kita buat RAB dan mengajukannya ke bendahara, kemudian bendahara atau operator memasukkannya ke Siskeudes membutuhkan waktu yang cukup lama, karena operator juga belum memahami dengan benar sehingga membutuhkan waktu, belum lagi terjadi perbedaan nama kegiatan di Siskeudes dan nama kegiatan yang ada di RAB kita yang berbeda, yaa tidak sesui, sehingga dibutuhkan konsultasi lagi ke kabupaten untuk menyesuaikan lagi, setelah itu kita buat yang sesuai, misalnya RAB kegiatan harus lebih rinci lagi".

Kesimpulan dari kedua pendapat informan tersebut bahwa dalam proses pelaksanaan dari aplikasi sistem keuangan desa (Siskeudes) ini haru disesuaikan dulu dengan apa yang ada pada sistem. Jika RAB tersebut tidak sesuai dengan apa yang ada dalam sistem, maka sistem tidak dapat menginput data. Tentunya hal ini juga dapat menghambat dalam bekerja, dimana operator atau staf pemerintah akan dituntut untuk bekerja dengan aturan yang telah ditentukan sehingga hasil kerjanya juga akan semakin baik. Selain RAB terdapat beberapa dokumen yang diinput dalam Sistem Keuangan Desa (Siskeudes) yaitu dokumen penatausahaan, bukti penerimaan, Surat Permintaan Pembayaran (SPP), Surat Setoran Pajak (SSP), laporan penganggaran (Perdes APBDesa, APBDesa per sumber dana), serta laporan penatausahaan (Buku kas umum, Buku bank, Buku pajak, Buku Pembantu, dan Register). Laporan- laporan yang akan diinput ke sistem, sebelumnya akan dibuat oleh pegawai yang bertugas yang telah dibagi ke bidang masing-masing. Setelah pegawai desa membuat rancangan laporan yang sesuai dan telah mendapat persetujuan selanjutnya akan diberikan kepada operator untuk diinput ke sistem. Pernyataan diatas dapat diperkuat juga dari hasil observasi yang diperoleh di lokasi penelitian.

Adapun prosedur penggunaan dari aplikasi System Keuangan Desa (Siskeudes) yang diawali dengan melakukan koneksi data, setelah data dikoneksi dengan menyesuaikan sistem pada kompuetr atau laptop, maka langka selanjutnya membuka Log in dengan menggunakan user Id Desa dengan langkalangka sebagai berikut:

1. Koneksi database harus dilakukan pada saat pertama kali aplikasi digunakan. Koneksi database disimpan dalam file config.ini pada folder aplikasi keuangan desa. Koneksi database secara default menggunakan tab koneksi Microsoft Acces. Database seperti tampak pada gambar berikut. 


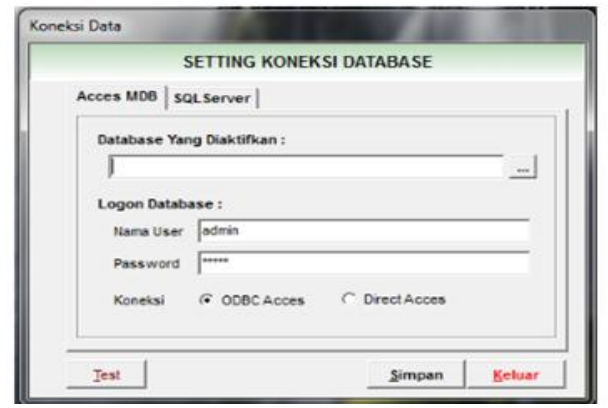

Gambar 1. Setting Koneksi Database

Pada inteface koneksi data tersedia 2 pilihan opsi koneksi, via ODBC (Open Database Connectivity) atau Direct Acces. Dengan koneksi via $O D B C$, aplikasi keuangan desa melakukan pembacaan data tidak secara langsung ke Driver MsAcces akan tetapi menggunakan mesin $O D B C$ pada sistem operasi windows. Sedangkan Direct Acces pembacaan file langsung dilakukan pada file database yang bersangkutan. Penggunaan opsi koneksi ODBC mengharuskan sistem komputer terinstall Microsoft Jet OleDB 4.0 pada Microsoft Office 2000-2003. Sehingga untuk komputer yang tidak terinstall office 2003 tidak dapat menggunakan fitur ini. Apabila ingin tetap menggunakan fitur ini adalah dengan cara menambahkan install aplikasi Office Acces 2003. Untuk memastikan apakah fitur ini dapat digunakan dapat dilihat pada Control Panel Windows pada tab System \& Security $\Rightarrow$ Adminstratif Tools $\Rightarrow$ Datasource $(O D B C$ seperti tampak pada gambar berikut.

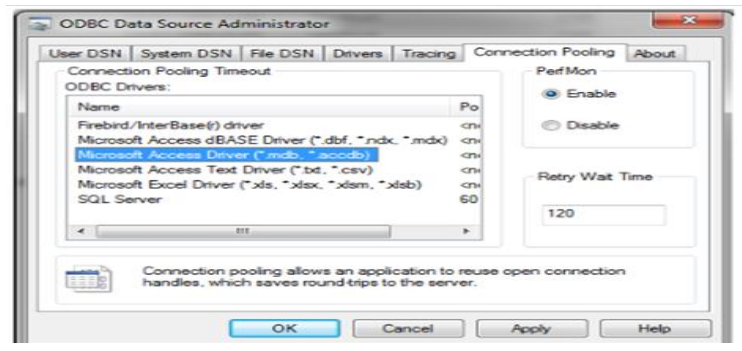

Gambar 2. $O D B C$ Data Administrator
Secara teknis penggunaan opsi via $O D B C$ lebih disarankan dan lebih menjamin keamanan data dari kerusakan (corrupt) dan dapat digunakan pada mode multiuser dengan cara melakukan sharing folder database "DataAPBDes.mde".

Untuk pemeliharaan data keuangan desa pada database microsoft acces, pengguna aplikasi agar melakukan compact and repair database secara berkala untuk memampatkan database. Proses ini dapat dilakukan minimal 1 bulan sekali. Cara melakukan compact and repair database adalah dengan membuka database aplikasi keuangan desa "DataAPBDes.mde" pada folder aplikasi dan memilih menu yang tersedia seperti tampak pada gambar dibawah ini

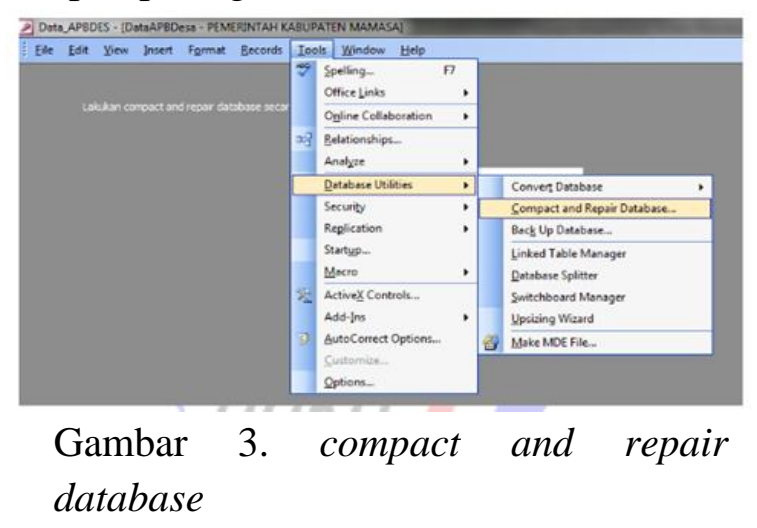

Log in ke sistem menggunakan user ID dan password yang dimiliki Desa Tokaka.

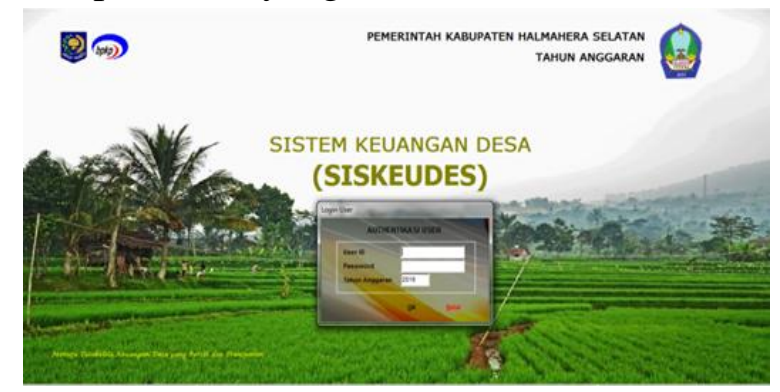

Gambar 4. Login SISKEUDES

Setelah membuka Siskeudes menampilkan menubar yang terdiri dari (file, Parameter, data Entry, Laporan, tools dan Help) yang akan digunakan sesuai dengan kebutuhan 
penginputan data pada Siskeudes. Sebagaimana ditampilkan pada gambar di bawah ini :

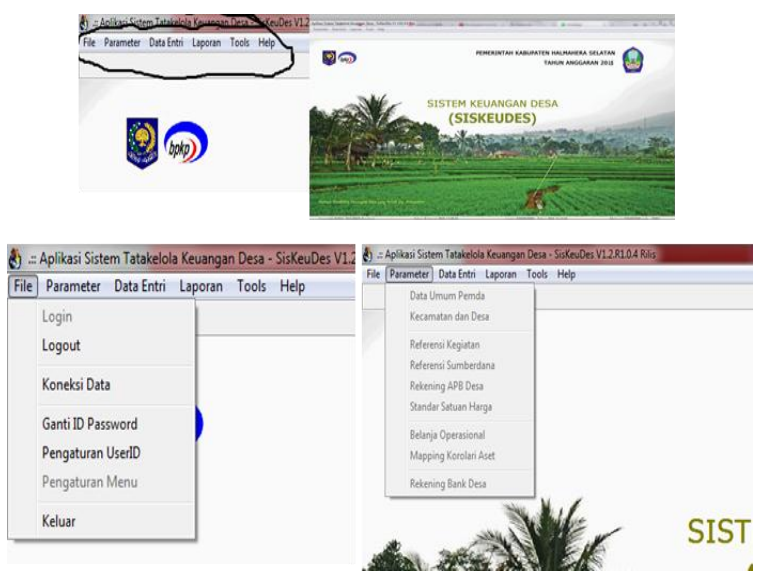

Gambar 5. Menu Sistem SISKEUDES

Setelah berhasil masuk ke sistem, lalu untuk memasukan data pilih Data Entri, kemudian pilih menu yang tertera. Dalam data entri terdapat 4 menu yang terdiri dari perencanaan,penganggaran,penatausahaan, serta pembukuan. Berikut tampilan program Sistem Keuangan Desa (SISKEUDES):

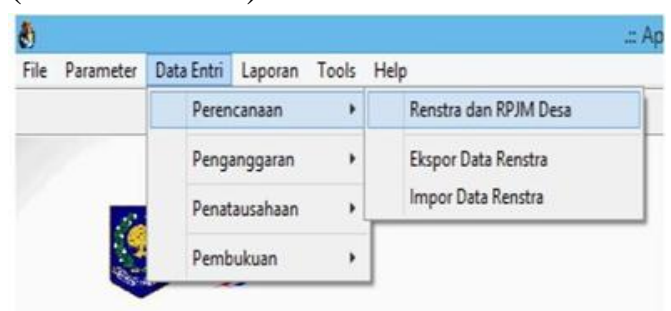

Gambar 4. Menu Data Entry

Isian Data Anggaran terdiri dari menu data umum desa, menu kegiatan, menu pendapatan, menu belanja, menu pembiayaan, dan menu pembiayaan 2 .

Posting APBDesa. Apabila proses input data anggaran telah selesai dan APBDes telah selesai dievaluasi maka posting APBDes dapat dilakukan. Posting ini dilakukan oleh admin Kabupaten/Kota atau admin di Kecamatan.

Cara Mengintegrasikan Sumber Daya Manusia (SDM) yang rendah terhadap
Penggunaan Sistem Keuangan Desa (SISKEUDES) menjadi problem di Desa Tokaka, karena harus membutuhkan peningkatan kapasitas dalam menyelesaikan problem untuk membantu meningkatkan kinerja kepala desa sebagai penyelenggaraan pemerintahan desa dalam hal secara administrasi dalam penataan keuangan desa. Hal ini secara teori dikemukana oleh Hasibuan (2007), bahwa Manajemen sumber daya manusia adalah suatu proses menangani berbagai masalah pada ruang lingkup karyawan, pegawai, buruh, manajer dan tenaga kerja lainnya untuk dapat menunjang aktivitas organisasi atau perusahaan demi mencapai tujuan yang telah ditentukan. Pengadaan tenaga kerja merupakan langkah pertama dan yang mencerminkan berhasil tidaknya suatu perusahaan mencapai tujuannya. Pengadaan adalah proses penarikan, seleksi, penempatan, orientasi, dan induksi untuk mendapatkan karyawan yang efektif dan efisien untuk membantu tercapainya tujuan perusahaan.

\section{Kendala Penerapan Sistem Keuangan Desa (Siskeudes) di Desa Tokaka}

kelemahan dari Sistem Keuangan Desa (Siskeudes) tersebut. Kelemahan Sistem Keuangan Desa (SISKEUDES) yaitu sulitnya memahami penggunaan aplikasi ini karena aplikasi yang masih baru diterapkan sehingga para pegawai sulit untuk mengaplikasikannya. Selain itu kuranganya pelatihan penggunaan sistem keuangan desa (Siskeudes) yang diberikan bagi para pegawai. Pelatihan aplikasi sistem keuangan desa (Siskeudes) hanya diberikan bagi operator yang bertugas sehingga para pegawai lainnya tidak memahami aplikasi tersebut dengan baik.

Disamping kelebihan dan kelemahan tersebut, adanya sistem yang baru 
diterapkan dalam suatu organisasi tentu menimbulkan kendala yang akan dihadapi oleh aparatur desa. Kendala tersebut antara lain: Sistem Keuangan Desa (Siskeudes) masih terbilang rumit bagi sebagian pegawai, kurangnya pelatihan dan terjadinya eror pada sistem. Kendala yang dialami tersebut sesuai dengan pendapat yang disampaikan oleh informan yaitu Bapak Muhidin Hi. Husen selaku Kepala Desa di Desa Tokaka yang menyatakan bahwa:

"Untuk hambatannya belum sinkronnya di pemerintah daerah, pendamping desa sehingga bahasa yang satu bisa yang lain belum tentu bisa. Karena aplikasinya juga masih baru, jadi operator atau bendahara desa juga masih agak bingung dalam penggunaannya. Nah apalagi tuntutan untuk dapat menggunakan aplikasi dengan benar".

Dari kendala-kendala tersebut tentu akan menghambat kerja dari para operator atau bendahara desa. Agar dapat mengatasi masalah tersebut, para operator dan bendahara berusaha untuk melakukan koordinasi berbagai pihak baik Pendamping Desa (PD/PLD) maupun operator dinas untuk dapat memaksimalkan pekerjaan sehingga mampu mengatasi masalah yang terjadi

\section{Dampak Kegunaan Sistem Keuangan Desa (Siskeudes) di Desa Tokaka}

Dampak dari kegunaan Siskeudes di Desa Tokaka yaitu :

1. Memberikan motivasi bagi para staf desa untuk bekerja dengan baik dan benar.

2. Kegiatan operasional yang lebih tertata secara administratif.

3. Mengurangi adanya kecurangan baik yang dilakukan secara sengaja maupun tidak sengaja.
4. Meningkatkan kinerja para Operator, bendahara desa atau kaur keuangan.

5. Dapat menggunakan Dana Desa atau Alokasi Dana Desa yang diberikan sesuai dengan kebutuhan pos atau bidang kegiatan yang ditetapkan dalam sistem.

6. Dapat menciptakan laporan keuangan sesuai dengan penatusahaan yang resmi. Namun disi lain,

7. SDM belum siap secara maksimal dalam mengoperasikan atau menjalankan sistem keuangan desa (Siskeudes) sehingga implementasi Siskeudes belum berjalan dengan baik di desa Tokaka.

Dengan demikian penerapan Sistem Keuangan Desa (Siskeudes) di Desa Tokaka belum berpengaruh secara signifikan terhadap kinerja kepala desa atau pemerintah desa, karena desa masih menggunakan penatausahaan secara manual dalam transaksi realisasi keuangan di desa, berupa Buku Kas (BKU), Buku Bank, Buku Bantu Pajak, Buku Bantu Kegiatan, dan bukti transaksi berupa nota dan kwitansi yang telah disusun secara manual. Sementara Laporan kegiatan Tahun Anggaran 2015 tahap pertama 40\%, tahap kedua $40 \%$ dan tahap terakhir $20 \%$, yang pelaporannya dalam bentuk Siskeudes hanya digunakan dalam penyampaian pelaporan keuangan ke pemerintah kabupaten, Meskipun pendidikan dari staf aparatur Desa Tokaka masih dibawah standar, karena yang tertinggi pendidikannya hanya pada Sekolah Menengah Atas (SMA) itupun hanya beberapa orang saja, yang lainnya dibawah itu, sehingga dapat mempengaruhi kinerja, apalagi rata-rata belum menggunakan laptop atau komputer, sehingga sistem keuangan 
desa (Siskeudes) di Desa Tokaka belum berjalan dengan baik

Oleh karena itu, berdasarkan uraian di atas terutama dalam keterbatasan SDM dalam menjalankan Siskeudes, maka cara yang dilakukan untuk mengintegrasikan sumber daya manusia (SDM) yang rendah terhadap penerapan Sistem Keuangan Desa (SISKEUDES) yaitu memberikan pendidikan dan pelatihan secara teratur, melakukan koordinasi dengan para pendamping desa (PD) maupun Pendamping Lokal Desa (PLD) atau Tenaga Ahli (TA) Kabupaten dan pelatih dari operator Kabupaten dalam hal ini adalah DPMD kabupaten, atau mengundang staf dari BPKP untuk memberikan dukungan dan motivasi bagi para staf/pegawai dalam memberikan materi proses pembelajaran siskeudes, menyediakan sarana dan prasarana yang akan digunakan guna meningkatkan sumber daya manusia (SDM).

\section{KESIMPULAN}

Berdasarkan pembahasan yang telah dilakukan, maka dapat disimpulkan sebagai berikut: 1). Penerapan sistem keuangan desa (Siskeudes) di Desa Tokaka belum memberikan kontribusi yang signifikansi terhadap kinerja kepala desa selaku penyelenggaraan pemerintahan di desa, karena masih menggunakan penatusahaan secara manual berupa BKU, Buku Bantu kegiatan, Buku bantu Pajak, Buku Bank dalam realisasi pengelolaan kegiatan dalam pelaporan, namun demikian sudah ada keinginan untuk memanfaatkan Siskeudes sebagai alat yang digunakan desa dalam penatausahaan keuangan desa khususnya Dana Desa (DD) dan Alokasi dana Desa (ADD) pada Tahun Anggaran 2015 sebagai tahun pertama dalam implementasi undang-undang No. 6
Tahun 2014 tentang Desa, yang hanya digunakan dalam pelaporan ke pemerintah daerah sebagai pemenuhan kebutuhan pelaporan pemerintah pusat . 2). Sudah ada potensi Sumber Daya Manusia (SDM) yakni operator Siskeudes yang juga selaku Kaur Keuangan sudah dapat mengoperasikannya, namun belum $100 \%$, karena terkendala dalam beberapa tahapan akhir seperti melakukan postingan data yang saat ini dilakukan oleh operator kabupaten sebagai pengendali Siskeudes kabupaten. Akan tetapi secara umum Sistem Keuangan Desa (Siskeudes) sebagian telah diketahui. 3). Sistem Keuangan Desa (Siskeudes) sebelum diterapkan ke desa dapat dilakukan peningkatan kapasitas pemerintah desa terutama bendahara desa atau operator desa sehingga siap dapat menjalankan Siskeudes sesuai dengan yang diharapkan oleh penmangku kepentingan dalam hal ini adalah pemerintah, karena anggaran yang bersumber dari APBN harus dikelola sesuai dengan makanisme dan aturan yang berlaku, sehingga desa telah siap dalam SDM.

Berdasarkan hasil yang disimpulkan sebelumnya, maka dapat disarankan sebagai berikut: 1). Sebagai tindak lanjut dari hasil penelitian dapat disarankan yaitu yang pertama bagi Desa Tokaka yaitu agar Sistem Keuangan Desa (SISKEUDES) dapat dipelajari sampai benar-benar dapat diketahui khususnya operator dan bandahara desa atau Kaur keuangan untuk dapat melakukan penginputan ke Siskeudes. 2). Pemerintah daerah dalam hal ini DPMD atau operator Siskeudes Kabupaten agar dapat memberikan pendapingan kepada operator desa sampai pada tahapan postingan data sehingga desa dapat mengentrol kesalahankesalahannya apabila terdapat kekeliruan 
dalam penginputan data. Walau demikian hasil penginputan tetap dapat divalidasi oleh operator kabupaten sebagai pengendali Siskeudes, dengan tujuan dapat menghindari kesalahan-kesalahan yang dilakukan oleh desa dengan menyandingkan laporan keuangan yang telah dibuat di desa. 3). Bagi peneliti sebagai referensi substansional dalam penelitian selanjutnya, karena penelitian ini mendapatkan banyak informasi tentang penting penerapan Sistem Keuangan Desa (SISKEUDES) sebenarnya merupakan salah satu sistem yang baik dan dapat digunakan untuk membantu operator desa dan benhara desa dalam membuat laporan keuangan desa, tanpa mengurangi kekurangan-kekurangan pada SISKEUDES, karena siskeudes juga masih terdapat kekurangan- kekurangan terutama isi menu-menu yang berhubungan dengan item-item kegiatan antara bidang 1 sampai dengan bidang 4 (Bidang penyelenggaran pemerintahan, pembangunan desa, pembinaan masyarakat dan pemberdayaan masyarakat) belum bersinergi dengan aturan kementerian dalam negeri, kementerian desa dan kementerian keuangan sehingga dapat membingungkan operator

\section{DAFTAR PUSTAKA}

Akbar, Norfan. 2015. BPKP Kawal Keuangan Desa Lewat SISKEUDES dan SIA BUM Desa. [Online Tersedia di https : // jpp. go. id/ nasional/pembangunan-desa/306394bpkp-kawal- keuangan-desa-lewatsiskeudes-dan-sia-bum-desa [Diakses pada 12 Desemberr 2015].

BPKP, 2015. Petunjuk Pengeoperasian Aplikasi Sistem Tata Kelola Keuangan Desa
Gunawan, Iman. 2013. Metode Penelitian Kualitatif: Teori dan Pratilik. Jakarta: Bumi Aksara.

Hasibuan, Malayu. S.P. 2007. Manajemen Sumber Daya Manusia. Jakarta: PT Bumi Aksara.

Herdiansyah, Haris. 2015. Wawancara, Observasi, dan Focus Groups: Sebagai Instrumen Penggalian Data Kualitatif. Jakarta: Rajawali Pers.

Mardiasmo. 2009. Akuntansi Sektor Publik. Edisi IV. Yogyakarta: BPFE.

Moleong, Lexy J. 2012. Metodologi Penelitian Kualitatif. Bandung: Remaja Rosdakarya.

Republik Indonesia. 2014. Undangundang No. 6 Tahun 2014 tentang Desa.

Sugiyono. 2012. Metode Penelitian Kuantitatif Kualitatif dan $R \& D$. Bandung: CV Alfabeta.

Susanto, Azhar. 2013. Sistem Informasi Akuntansi. Bandung: Lingga Jaya.

Wuryaningrum, Ambar. 2007. Pengaruh Teknologi Informasi Terhadap Kinerja Individu dengan Kepercayaan dan Kompleksitas Sistem Sebagai Moderating Variabel. Skripsi. Malang: Universitas Brawijaya.

Jehan M.Malajika, Herman Karamoy, Rudy J. Pusung, Penerapan Sistem Keuangan Desa (SISKEUDES) Pada Organisasi Pemerintah Desa (Studi Kasus Didesa Suwaan Kecamatan Kalawat Kabupaten Minahasa Utara), Jurnal Riset Akuntansi Going Concern 13(4) 2018, Hal 578583 